\title{
The American Dream in Fitzgerald's The Great Gatsby
}

\author{
Ayub Muhammad Haji \\ Cultural and Social Center - Salahaddin University-Erbil - Iraq \\ Email: ayubmuhamad@yahoo.com
}

\begin{abstract}
The paper explores the corrupted idea of the American Dream in one of the greatest novels written on the topic, The Great Gatsby by F. Scott Fitzgerald. Even though the pursuance of the American Dream stems from the idea of hard work and success that is pure, truthful, and just, Jay Gatsby's approach as a protagonist in achieving it leads to his demise. His relationships with other characters, particularly Tom Buchanan and Daisy Buchanan, were tainted because of the morally corrupted notion of the American Dream. This paper textually analyzes The Great Gatsby and explores that how Gatsby runs after a dream (Daisy) that he cannot achieve even after becoming financially wealthy, and how the corrupt ideals of the American Dream become the reason that he cannot fulfill his own dreams.

In many ways, The Great Gatsby represents Fitzgerald's attempt to confront his conflicting feelings about the Jazz Age. Like Gatsby, Fitzgerald was driven by his love for a woman who symbolized everything he wanted, even as she led him toward everything he despised.
\end{abstract}

Keyword: American Dream, Jazz Age, Lost Generation, Morality, Ideals. 


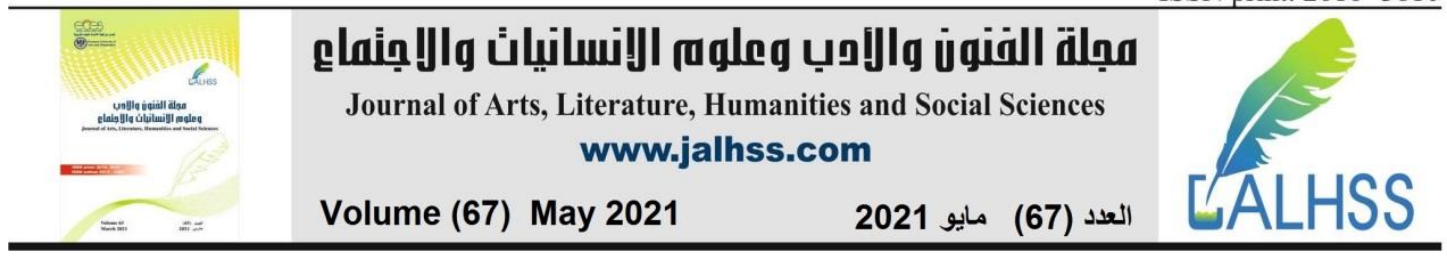

\section{Introduction}

The American dream has been accepted by numerous and assumed to be the exemplification of America's presence. This thought, has been idealized as a dream, and generally depicted America as the arrive of bounty, boundless notoriety, victory and thriving. With the passage of time, this conviction and ideal has been subsiding into distraction, devastation, and vanishing nearly totally. The disintegration of this dream has been genuine since the nineteen twenties; a period between the world war and the great depression, known as the Jazz Age. This specific period enlisted momentous changes within the social, political and financial environment in America.

\section{Benjamin Franklin}

If one takes the time to look at the life of Benjamin Franklin, this trend gets to be apparent indeed within the most punctual days of American society. The section that best depicts Benjamin Franklin is as takes after: He was a veritable item of American Soil. His mother mind served him way better than learning, and his prepared information of human nature was a priceless asset. He was canny and adroit; judicious, however strong; thrifty, however liberal. An understudy of logic, but a man of the world. He took hold of anything he did that he might work out a few substantial results. Nothing came to him by good fortune, but everything through labour (Hill 8).

\section{Franklin is the Embodiment of the American Dream}

Franklin's life embodies the original version of the American Dream, it is imperative to look at where he came from and fair how distant he got with no exterior offer assistance from his possess assurance. Benjamin Franklin was put within the way of getting to be broadly valuable to his claim era and distinguished sometime recently the world. He had an enthusiasm for perusing. That was the brilliant key which opened his entirety future. He went from being a standard man to fulfilling exceptional things that changed the confront of the advanced world forever.

\section{Some of these extraordinary accomplishments include:}

- $\quad$ Writing the Declaration of Independence.

- $\quad$ Inventing the Franklin Stove.

- Inventing the lightening rod as well as the bifocal glasses.

- $\quad$ Conducting experiments to prove the existence of lightening.

- $\quad$ Singing the treaty that ended the Revolutionary War (Usel 8).

(Benjamin, F.,1998). 


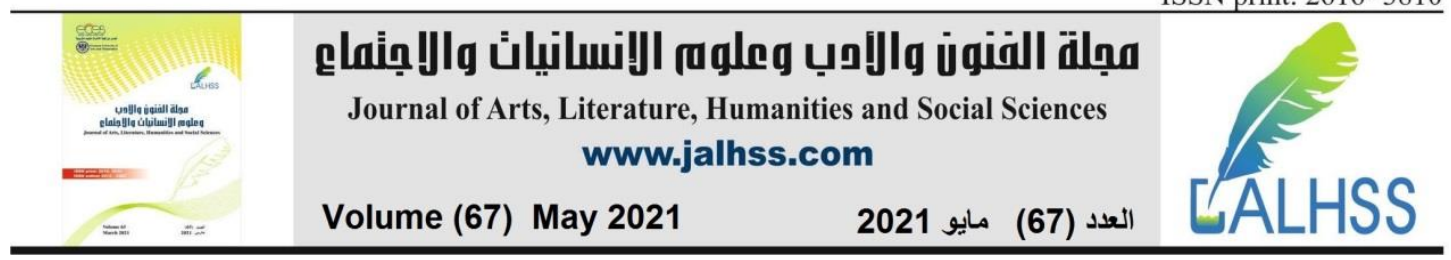

\section{The Jazz Age}

The Jazz Age was an item of a one of eras known as The Lost Generation. This generation was one which was entirely distinctive from any which America had seen some time recently due to the truth that not at all like past eras, this specific gather was absolutely purposeless. Developing up in an America that had survived the Primary World War, made them feel as in the event that all fights had been fought for them hence now not motivating the ought to work towards objectives or dreams. Instep, this generation went through a lion's share of their time locks in in wild parties and drinking their distresses absent in trusts of supplanting the sense of misfortune that stemmed from having no objectives or desire. The Jazz Age was a coordinate result of the disappointment of the American Dream. The Lost Generation was an encapsulation of both the failure of the American Dream and the Jazz Age.

The Jazz Age Formally, the term can be defined as the period between the years 1919 until October, 1929, years which acted as a buffer between two great events-- the World War I and the great depression (Boardman 7).

\section{Glamour \& Luxury}

To understand the extent to which the age esteemed glamour, one can take a clue from the terrific and luxurious lodgings that were developed amid this time. They essentially act as a changeless respect to the values of extravagance and excess that the Jazz Age mercilessly advanced. In spite of the numerous a long time that have passed, these inns still stay unravelled in their detail, recommending that no matter how numerous a long time have passed, there has not been another time when America fell so profound into the profundities of realism.

\section{The start of the Jazz Age indicated, the failure of the American Dream}

By the time the Jazz Age had come into full swing, the first American Dream had as of now declined and taken with it the concept of hardworking. Numerous of the previous generation, still seen America as a arrive where freedom was important, however a certain degree of morality was continuously required to form beyond any doubt that society remained in arrange. The ethics of hard work and sacrifice were required particularly amid the Primary World War, in a sense, their American Dream of dedicated, profound quality and morals gradually vanished amid the Jazz Age. The unused American Dream still spun around advance but with advance came the require for extravagance that the past era had not permitted themselves to enjoy in.

\section{The Lost Generation}

(Allen. F, 1931).

Who was formally a part of the so-called Lost Generation isn't however clearly characterized? There are those who contend that the term alludes as it were to those writers who lived in Europe between the two World Wars. Whereas others demand that the term does not relate only to writers but also to a complete post-war era, "The impact of the Lost Generation has resounded distant past scholastic and literary circles 


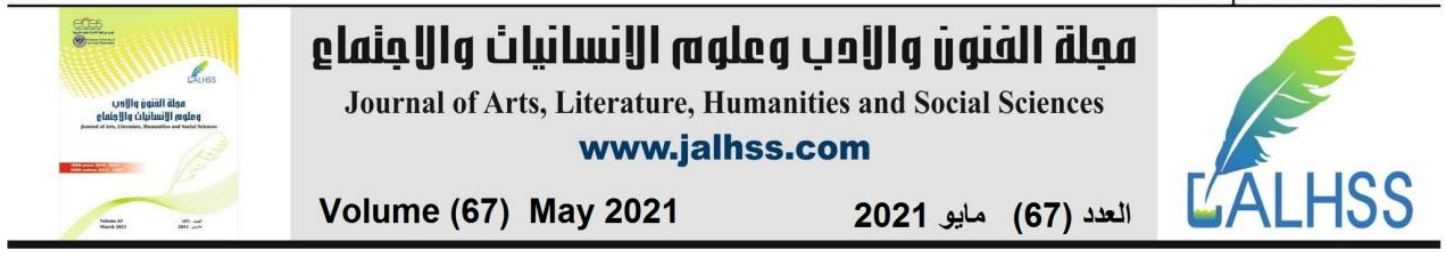

in prevalent movies, tv-series, used-clothing shops, and indeed subject bars" (Monk1). The term was, to begin with, coined by Gertrude Stein in which she utilized to portray writers such as Hemingway and Fitzgerald.

The Lost Generation moreover felt tweaked absent from connection to any region or tradition by the colleges they gone to or the cities they run to....in claiming for themselves the uncommon charm--to borrow another one of Fitzgerald's titles--of the perfectly cursed, they named themselves prophets of their age, a part most of them clearly favoured to that of a social reformer. They were by turn nostalgic, care-free, fun cherishing, stricken, pleased, and insubordinate. But they realized that the national propensity of feeling uncommon implied nothing in the event that it did not incorporate doing something that was special (Berovitch, and Pattell 10).

\section{What exactly does "Lost" mean in the context of the Lost Generation:}

It is basic to require a closer look at the word "Lost". The word can take on two implications. To begin with, it can be utilized to portray the lack of morality that characterized this post-war generation, "The lost quality of the Lost Generation alluded to its morality; American writers overseas between the World Wars had surrendered their ethical heading once in Europe and repelled themselves from conventional standards" (Monk 4). The insignificant truth that these scholars or specialists, in general, had the ought to take off America and seek after life in another country whereas abandoning the American standards of difficult working and assurance could be a clear sign that the American Dream had begun to fade and decline.

(Callahan, J., 1996)

\section{Literature Review and Analysis}

\section{The Characters}

Jay Gatsby: Jay Gatsby appears to be the embodiment of the American dream at the novel's opening. The self-made man is depicted as a wealthy, charismatic businessman who, having amassed a fortune, has built himself a lavish lifestyle in post-war America. From the outset, Gatsby is elusive and mysterious, the stories of where he came from and how he amassed his wealth are as numerous and fanciful as the people who attend his weekly parties. Nick Carraway eventually learns that Gatsby was born James Gatz, the son of a poor farming family from North Dakota. The Jay Gatsby of West Egg is an invention of the young James Gatz, who wanted a different, sophisticated life for himself. Gatsby keep his origins a secret and presents to the public only what he wants them to see. The mystery leads people to speculate. Some people are certain he was a German spy; others say he acquired his money through illegal activities such as gambling and alcohol. Still others insist he killed a man. Gatsby does not care what others think of him. His entire focus is building his wealth, power, and prestige, all in an attempt to make himself worthy of Daisy Buchanan, a 




young woman he had fallen in love with before the war. But Gatsby's dreams, like the identity he created for himself and the extravagant life he leads, are hollow and fleeting and eventually lead to his downfall. Gatsby represents both the best and the worst of the American dream; without a proper foundation, that dream is all just a light in the distance: bright, intriguing, and unattainable. Gatsby's downfall, particularly the bleakness of his funeral, can be read as a critique of the reckless indulgence in pursuit of that dream.

Nick Carraway: Nick Carraway, the novel's narrator, is a bright, insightful young man who has recently returned from duty in World War I. Despite being raised in the Midwest, Nick moves to New York to work as a bond's tradesman. Nick is portrayed as an honest, fair, and impartial man who makes friends easily and often serves as a mediator among both friends and acquaintances. He witnesses the dichotomy between the poor and elite, causing him to struggle with the superficiality of affluence.

Daisy Buchanan: Daisy Buchanan is the superficial, self-absorbed, flighty, and even foolish woman Gatsby is in love with. Married to the wealthy but arrogant Tom Buchanan, Daisy has an affair with Jay Gatsby, her former lover. Throughout the novel Daisy rarely displays any emotion beyond her apparent boredom; she lives as if simply going through the motions. When Tom confronts Gatsby about his affair with Daisy, she quickly abandons Gatsby, quitting their game. Daisy represents the wealthy women during this era, many of whom were referred to as flappers for their forays - in dress, behaviour, and thought - into the modern life they embraced in the 1920s. Daisy's final act, running from the responsibility of her car accident, suggests that she is a risk-taker only if it does not risk her real life and the privileges it affords her.

Tom Buchanan: Tom Buchanan is a boisterous, unruly, arrogant brute. Tom is selfcentred and controlling, showing a complete lack of respect for (and sometimes abuse of) women, including his wife and mistress. Throughout the novel, Tom manipulates situations and people to hide his indiscretions. Representing the elite, Tom looks down on those without money and those with new money.

George Wilson: George Wilson owns and operates Wilson's garage and gas station in the valley of ashes. Unlike his wife, Myrtle, George is resolved to his position in life, a quality that spurs Myrtle's contempt for him. In his dealings with the world, George is respectful and fair, even with those who treat him poorly, like Tom Buchanan. In the end, his heartbreak over Myrtle's death leads him to murder, and ultimately suicide, representing the tragic impact of greed and deceit.

Myrtle Wilson: Myrtle Wilson is Tom's married mistress. She lives in the valley of ashes with her husband, George. The valley of ashes is a financial and social wasteland, and Myrtle wants to escape it for a better life. She believes herself desirable to wealthy men and dislikes her husband for being poor. She represents lower class striving for the wealth, prestige, and lifestyle of the elite. 


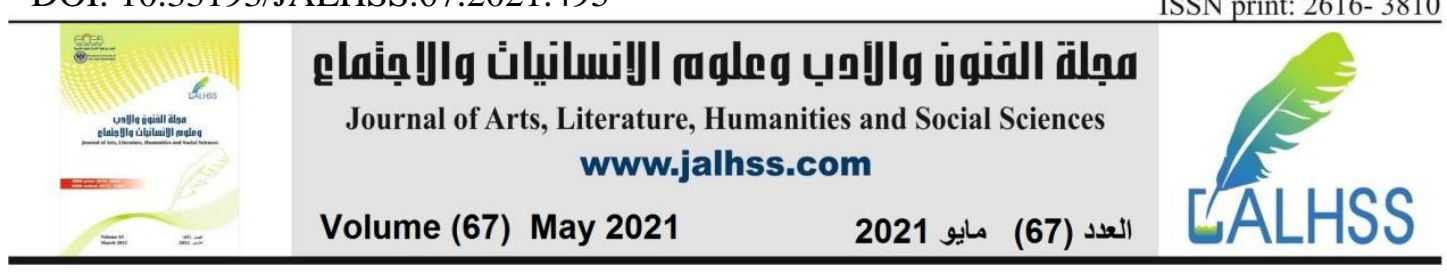

Jordan Baker: Jordan Baker is Daisy's friend from girlhood and a wealthy professional golfer. Jordan represents the new woman of the 20th century, and is more of a risk-taker than her childhood friend. She ignores social conventions, speaks directly, and cheats to get what she wants. She becomes romantically involved with Nick, but their relationship deteriorates when Nick discovers her dishonesty.

(Fitzgerald, F., 1986).

\section{Quotes}

"Whenever you feel like criticizing anyone, just remember that ... [everyone hasn't] had the advantages that you've had."

- Mr. Carraway, Chapter 1

In the opening of the novel, Nick recalls this advice from his father and says that it causes him to reserve judgment on people and to be open to those who want to share their thoughts.

"I hope she'll be a fool-that's the best thing a girl can be."

— Daisy Buchanan, Chapter 1

This quote shows that Daisy is not truly content with her role as a frivolous, wealthy wife. Although that role is the most she can foresee for her daughter, she is not happy about that either.

"I told that boy about the ice. ... You have to keep after them all the time."

— Myrtle Wilson, Chapter 2

Through her affair with Tom, Myrtle believes she is part of the elite and pretends to be a snob at the hotel. She is distorting reality, ignorant that she will never be fully accepted.

"Before the wedding he gave her a string of pearls valued at three hundred and fifty thousand dollars."

— Jordan Baker, Chapter 4

Jordan explains why Daisy married Tom, even though she was in love with Gatsby. Tom offered financial security and social prestige that she couldn't pass up.

"They're such beautiful shirts ... I've 


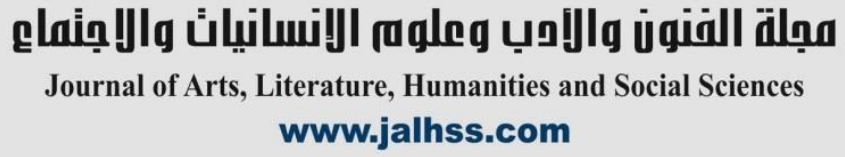

never seen such beautiful shirts."

— Daisy Buchanan, Chapter 5

Daisy sobs when she sees the wealth Gatsby has amassed. She realizes that she could have had it all-love and money — if she had waited for him as she promised she would.

"He invented ... the sort of Jay Gatsby that a seventeen-year-old boy would ... invent."

— Nick Carraway, Chapter 6

In pursuing his version of the American dream, Gatsby remakes himself into what he believes, on a superficial level, to be the ideal man: a wealthy socialite moving upward on the social scale.

"You always look so cool."

— Daisy Buchanan, Chapter 7

This is Daisy's roundabout way of telling Gatsby that she loves him, but it focuses on his appearance, serving as a reminder of how shallow Daisy's love is.

"I go off ... and make a fool of myself, but I always come back."

— Tom Buchanan, Chapter 7

Tom justifies his extramarital affairs because in his heart, he loves Daisy and always comes back to her, which highlights his immorality and selfishness.

"What'll we do ... this afternoon ...

and the day after that, and the next thirty years?"

— Daisy Buchanan, Chapter 7

Although Daisy usually maintains a cheerful demeanour, this line reveals that she is sad about what she sees as the meaninglessness of her life.

"So we drove on toward death through the cooling twilight."

— Nick Carraway, Chapter 7

The line also foreshadows the evening's events: Gatsby and Daisy are ahead of them in Gatsby's car and will soon have the tragic accident that results in the death of Myrtle Wilson. 


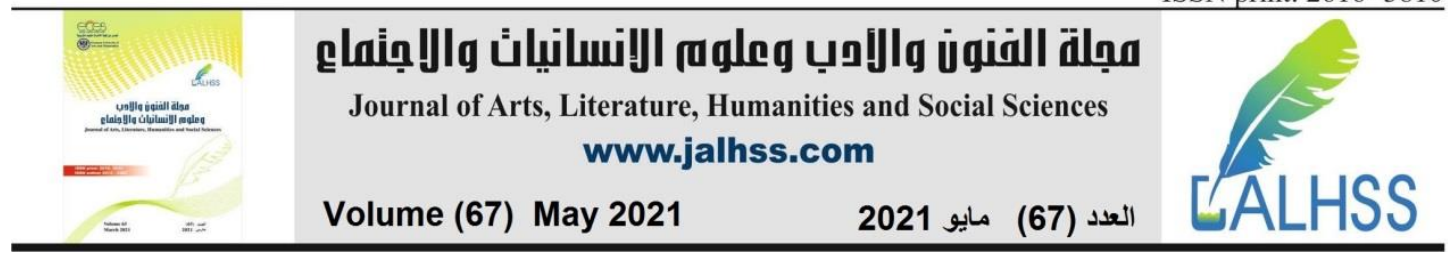

Nick, musing on his 30th birthday, sees ahead of him a rather gloomy future of dwindling social prospects and loneliness, leading eventually to death.

"You're worth the whole damn bunch put together."

— Nick Carraway, Chapter 8

Nick has come to truly care about Gatsby, despite his criminal behaviour. Gatsby embodies passion and single-minded determination, which Nick respects much more than being born into an elite position.

"You may fool me but you can't fool God!"

— George Wilson, Chapter 8

After Myrtle is killed, George tells his neighbour Michaelis that

he had warned her that God is all-seeing. Despite the disregard for institutionalized religion during the 1920s, George reminded his wife that there are still consequences for immoral behaviour.

"They smashed up things ... and then retreated back into ... their vast carelessness."

- Nick Carraway, Chapter 9

Describing Tom and Daisy, Nick realizes that the wealthy can always hide behind their money, which perpetuates their immorality and sense of entitlement.

"Gatsby believed in the green light, the ... future that year by year recedes before us."

— Nick Carraway, Chapter 9

Daisy still had feelings for Gatsby, but her love for Tom and Pammy could not be overcome; her current life destroyed any possibility for Gatsby's longed-for future. Although he believed that his idealized future was possible, his attempt to re-create their past love failed because Daisy's present, including Tom and their daughter, could not be ignored.

This quote repeats Gatsby's dream of a future based on his past romance with Daisy.

(Fitzgerald, F., 1986). 


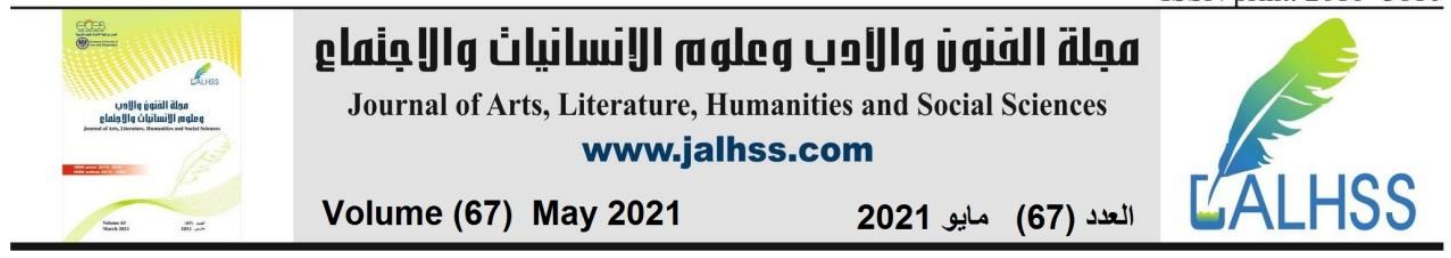

Analysis

\section{Chapter One:}

1. The green light Gatsby reaches toward is deeply symbolic: in literature, green is often symbolic of money, and Nick later realizes that the light emanates from the end of the Buchanans' dock.

2. As the novel progresses, it is revealed that Gatsby has amassed all his wealth in the hopes of winning Daisy's love - a desire perfectly symbolized in this scene.

3. On the other side of the bay, new-money residents, like Jay Gatsby, aren't quite accustomed to their great wealth yet, making them emotionally vulnerable (they know what they have to lose).

4. His father's advice to avoid criticizing people because "all the people in this world haven't had the advantages that you've had" suggest that he is nonjudgmental and moral, which is the perfect lens through which to view this story of deception, superficiality, and immorality.

5. Because Nick is well-educated and comes from a good background, it's clear that he will fit easily into both social circles - the old money of East Egg and the new money of West Egg.

\section{Chapter Two:}

1. Fitzgerald uses the stark contrast between the valley of ashes, the Eggs, and New York to vividly represent the socioeconomic status of the people living in these areas.

2. Using the gathering at Wilson's garage in the valley of ashes as a backdrop, the contrast between the Buchanans and the Wilsons is clear.

3. Her behaviours are affected and obviously mimicked, but she is eager to display the fantasy life she has created for herself-including the puppy, her newest domestic accessory toward which she displays a superficial affection.

4. George seems content with his station in life, while Myrtle (like Jay Gatsby) longs for attention and affluence.

\section{Chapter Three:}

1. Nick also seems concerned with how his character comes across in the novel, speaking directly to readers to assure them that he didn't fritter away his summer with mindless partying - he worked hard in New York and tried to date other women.

2. Nick's personal ethics can be glimpsed as he muses on what he calls Jordan's "incurable dishonesty." He is drawn to both Gatsby and Jordan despite their seeming dishonesty (or hidden truths). 


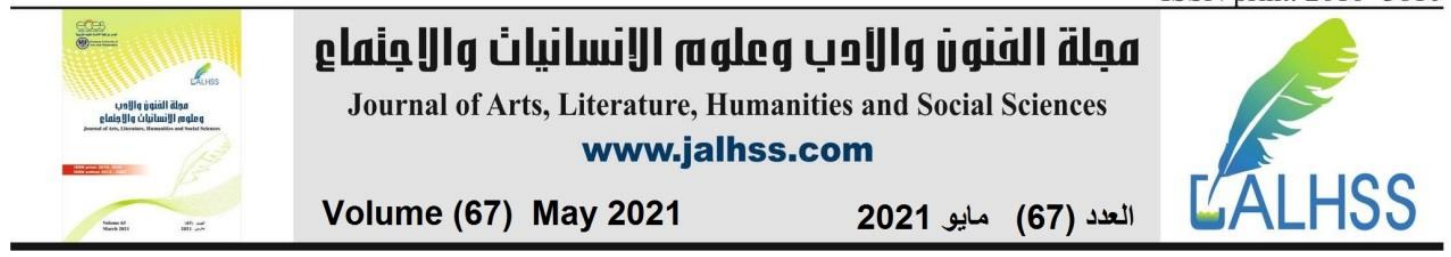

3. Gatsby's accent, however, seems fake; he throws parties where he knows none of the guests, and in touring his home, it's clear that each detail has been painstakingly chosen to create the appearance of vast wealth.

4. Despite Gatsby's fame, Nick is taken aback by how humble the man seems, and is surprised to learn that they served in the same military division during the war.

5. Gatsby is symbolic of the new money of West Egg: people who aren't used to being rich and are thus prone to lavish displays of wealth, such as his opulent parties.

6. No one seems to know who Gatsby is or how he got rich, but they're more than happy to take advantage of his generosity by partying into the wee hours of the morning, eating the food and drinking the wine of a host they cannot even identify.

\section{Chapter Four:}

1. Nick's fears of Gatsby being involved in organized crime are a sharp contrast to Jordan's perception of Gatsby as a broken-hearted soldier who would stop at nothing to win back the woman he loves.

2. Through these lies, the true picture of Gatsby is beginning to emerge: like many other characters in the novel, he is dishonest and obsessed with appearances.

3. Gatsby's clout hints again at his involvement in organized crime - the officer practically apologizes to Gatsby for pulling him over, rather than reminding him of the law.

\section{Chapter Five:}

1. When he knocks on Nick's door after Daisy's arrival, he is "pale as death." Gatsby wants everything to be perfect for Daisy, so he micromanages every detail to ensure it's as beautiful as he's always dreamed, hiring a landscaper to cut Nick's lawn, and sending over a "greenhouse" of flowers.

2. The build-up to their meeting is comically awkward, although Nick insists "it wasn't a bit funny." Gatsby, who has been controlled and measured throughout the novel, is suddenly nervous, emotional, and vulnerable.

\section{Chapter Six:}

1. Nick tries to shake sense into Gatsby by warning that he can't re-create the past, but Gatsby responds incredulously, "Of course you can!" Gatsby has been so dedicated to chasing a dream that he no longer sees its impossibility.

2. His dream won't be complete until Daisy admits that she never loved Tom, leaves him, and runs back to Louisville to marry Gatsby. 


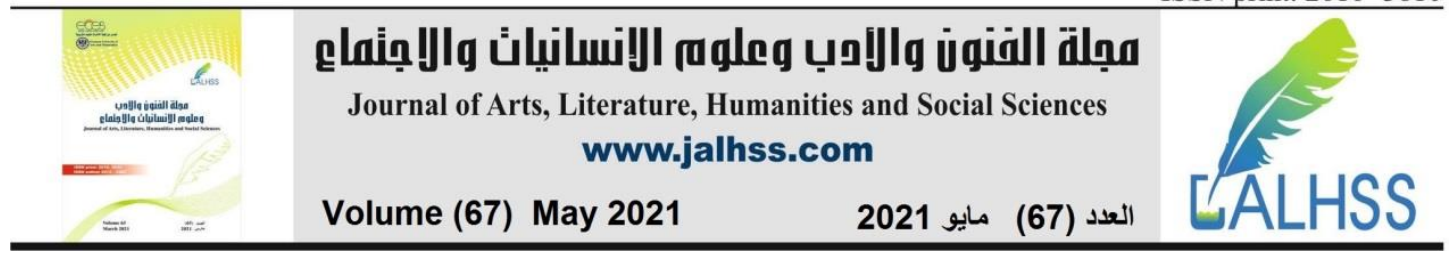

3. Gatsby foolishly thinks he can buy their friendship, just as he tried to do with Nick in Chapter 5, and he becomes a laughingstock.

\section{Chapter Seven:}

1. While Daisy dotes on her daughter, Gatsby "kept looking at the child in surprise." Although Daisy treats the toddler with what seems like a superficial display of attention, Pammy represents the love Daisy and Tom share, and denying that love is as ludicrous as trying to deny the child's existence.

2. The difference between Gatsby and the Buchanans is made clear one final time: while the Buchanans are united in their perverse view that everyone is disposable (Myrtle and Gatsby, for example) and are able to calmly sit and eat dinner together, Gatsby still wants to protect his perfect image of Daisy.

3. Tom cements this truth in the hotel room when he states, "there's things between Daisy and me that you'll never know." Indeed, Gatsby's money cannot erase Daisy and Tom's shared future in their daughter.

4. Gatsby's retelling of the hit-and-run suggests that Daisy intentionally mowed Myrtle down, hinting at Daisy's mindset leaving the hotel: if she can't have fun with Gatsby anymore, then she's going to ensure Tom can't have fun with his mistress, either.

5. The tension that has been mounting blows open in the climactic moment when, after a heated fight, Daisy chooses Tom over Gatsby.

6. Daisy's choice is foreshadowed before lunch when her young daughter appears, breaking the romantic moment she and Gatsby shared.

7. Realizing that he might lose Daisy, Tom admits his affairs, and promises "I'm going to take better care of you from now on." This seems to be enough for Daisy, who at the chapter's end, sits calmly eating dinner with her husband, uncaring that she has just killed a woman and broken a man's heart.

8. After the hotel room fight, Daisy's intentions in her relationship with Gatsby are revealed.

9. In the end, Gatsby's fantasy cannot trump the reality of the life Daisy and Tom have created, despite its obvious flaws.

10. Interestingly, Daisy repeatedly calls Pammy "dream," highlighting that her dreams are far different from Gatsby's.

\section{Chapter Eight:}

1. Eckleburg's eyes returns in this chapter, with George insisting that while Myrtle may have been able to fool him, she "can't fool God." When George looks up at the faded billboard, the reader is reminded how easily the characters have shed their morality in pursuit of personal gains (wealth, romance, and so on). 


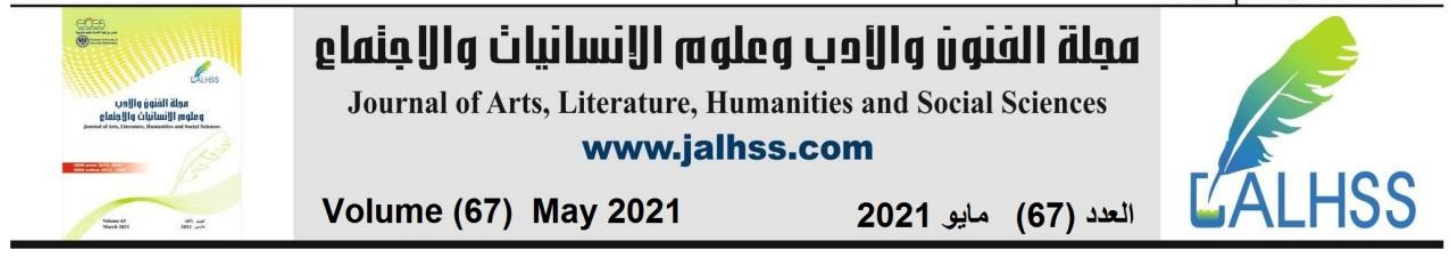

2. Fitzgerald is here again examining the idea of class struggle, with Myrtle, George, and Gatsby representing collateral damage - casualties of the games the rich can afford to play.

3. Spiritually, he feels "married" to her because they consummated their relationship five years ago, but Daisy obviously didn't feel the same way, yet Gatsby - the perpetual dreamer-still clings to the idea that Daisy has lost her way and needs him to save her.

4. Gatsby has fantasized his relationship with Daisy for so long that he cannot come to grips with the idea that she has changed since he first met her.

5. He shows genuine care for Gatsby, more concerned about his friend than his family (Daisy), urging him to leave Long Island until the dust has settled around Myrtle's death.

6. As frustrating as Gatsby's dreams are, Nick prefers them to the moral emptiness of the "rotten crowd" Daisy and Tom are a part of.

\section{Chapter Nine:}

When Nick visits Gatsby's house one last time, he sees the green light and imagines how Gatsby must have believed his dream to be just out of grasp, not realising that "it was already behind him, somewhere back in that vast obscurity." For Myrtle and Gatsby, being born poor prevented them from being truly accepted into the elite rank of social hierarchy, and no matter what either accomplished, acceptance would be impossible.

(Fitzgerald, F., 1986).

\section{The Main Themes in The Novel}

Valley of Ashes: Like many locations in The Great Gatsby, the valley of ashes is symbolic of its residents' social status, but the symbolism found here goes even further. The valley, which is covered in ashes from the neighbouring New York City factories, becomes symbolic of the waste left behind in the pursuit of wealth. The Wilsons, residents of the valley of ashes, are collateral damage in the wake of the Buchanans' elitist, immoral pursuits.

Green Light: The green light at the end of the Buchanans' dock is there for a practical purpose: it is a beacon to alert boaters that there is an obstacle there that they need to avoid. For Gatsby, the light symbolizes a dream - his dream of obtaining Daisy. In broader terms it also symbolizes the American dream. The novel opens with Gatsby reaching his open arms toward the light, and ends with Nick's realization that the dream is elusive: "tomorrow we will run faster, stretch out our arms farther." The novel questions the sacrifices individuals must make to achieve their dreams, and whether the ends justify the means. 


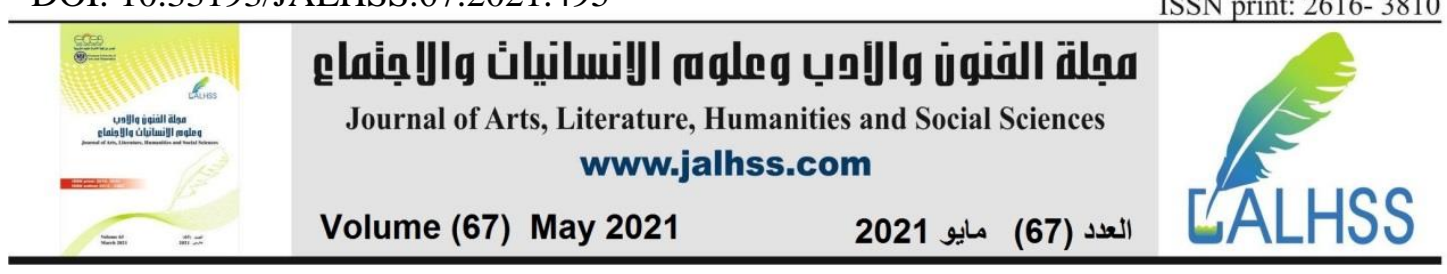

The Eyes of Dr. T.J. Eckleburg: The abandoned billboard promoting Dr. T.J. Eckleburg's optician services is symbolic of the immorality of the 1920s. In a time of fierce capitalistic gains and elaborate, wild parties, many Americans abandoned their religious morality in pursuit of personal pleasure. The billboard serves as a reminder of God's watchful eyes, yet it's faded, forgotten appearance suggests that the characters (with the exception of George Wilson) are no longer concerned with the consequences of their actions. Even George Wilson, who believed that God's eyes were watching down from the billboard, eventually breaks down and commits an immoral act by murdering Jay Gatsby.

(Gross, D., \& Gross, M., 2008)

\section{Conclusion}

The story of The Great Gatsby revolves around the failure of the American dream. Gatsby was poor, a social notion that put him out of the question of gaining Daisy's hand in marriage. Then he got rich, tried to achieve the American dream by doing illegal businesses in order to set himself on the pedestal of 'a rich man marrying a rich woman' in order to justify his love. Though Daisy Buchanan and Jay Gatsby come from very different backgrounds, they are similar because they are both addicted to achievement: their unrealistic expectations and constant need to look to the future prevents them from ever being happy.

Using these characters Fitzgerald is shows the reader how the American dream can never make anyone happy because the person will always just want more. The author is portraying that to be happy, people cannot have boundless goals, but instead need to learn to appreciate the present, rather than obsess on how great the future will be. The American dream is shown with the characters of Gatsby and Myrtle. Both the characters come from a low-income family and wish to live their American dream by accumulating wealth. They move to every length to fulfil their dream. Gatsby follows the life of illegal stores while Myrtle becomes a mistress to a wealthy man, Tom. Both their ambitions come to life, but their lives are ultimately shallow and incompetent. Their lives are short-lived, as both are killed soon after they acquire wealth and fame. The novel's main message is that shortcuts cannot fulfil the American dream, but it needs hard work. 


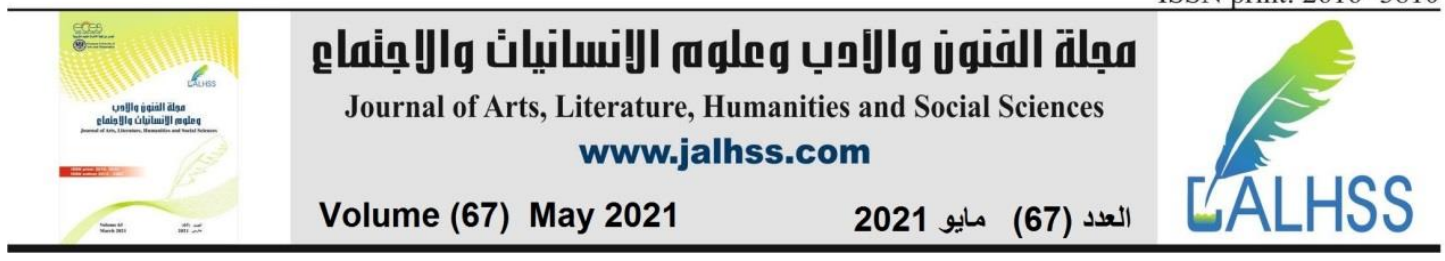

\section{References}

1. Allen, Frederick Lewis (1931). Only Yesterday: An Informal History of the Nineteen-Twenties.

2. Batchelor, Bob (2013). Gatsby: The Cultural History of the Great American Novel. Lanham, Maryland: Rowman \& Littlefield.

3. Berman, Ronald (1996). The Great Gatsby and Modern Times. Champaign, Illinois: University of Illinois Press.

4. Benjamin, F. (1998).“ Autobiography." Autobiography and Other Writings. Oxford and New York: Oxford University Press.

5. Bloom, H. (1986). F. Scott Fitzgerald's The Great Gatsby. New York\Philadelphia: Chelsea House Publisher.

6. Bruccoli, Matthew Joseph, ed. (2000). F. Scott Fitzgerald's The Great Gatsby: A Literary Reference. New York City: Carroll \& Graf Publishers.

7. Callahan, J. (1996). F. Scott Fitzgerald's Evolving American Dream: The "Pursuit of Happiness" in Gatsby, Tender Is the Night, and the Last Tycoon. NineteenthCentury Literature, 42, 374.

8. Fitzgerald, F. (1986). Scott. The Great Gatsby. New York: Collier Books, Print.

9. Gross, D., \& Gross, M. (2008). Understanding The Great Gatsby. Beijing: China Renmin University Press.

10. Ousby, I. (1979). An Introduction to 50 American Novels. London: Pan Books Ltd.

11. Piper, H. D. (1970). Fitzgerald's The Great Gatsby: The Novel, The Critics, The Background. New York: Charles Scribner's Sons.

12. Wang, Z. L. et al. (1992). European Culture: An Introduction. Beijing: Foreign Language Teaching and Research Press. Wei, Y. Q., \& Li, J. (1998). New Testament. Tianjin: Tianjin People's Publishing House. 